\title{
GENETIC DIVERSITY OF THE FRESHWATER SNAIL BIOMPHALARIA TENAGOPHILA (D'ORBIGNY, 1835) (GASTROPODA: HYGROPHILA: PLANORBIDAE) ACROSS TWO COASTAL AREAS OF SOUTHEAST BRAZIL
}

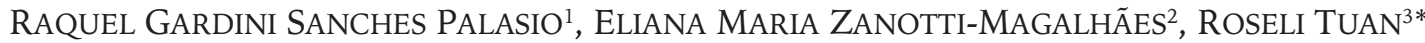 \\ ${ }^{1}$ School of Public Health USP, Avenida Doutor Arnaldo 715, 01246-904 São Paulo, Brazil \\ (e-mail: raquelpalasio@usp.br) \\ ${ }^{2}$ University of Campinas, Rua Monteiro Lobato 255, 13083-862 Campinas, Brazil \\ (e-mail: emzm@unicamp.br) \\ ${ }^{3}$ Superintendence of Control of Endemic Diseases, Rua Paula Sousa 166, 01027-000 São Paulo, Brazil \\ (e-mail: rtuan@sucen.sp.gov.br) \\ *corresponding author
}

\begin{abstract}
This study uses two mitochondrial (COI, 16SrRNA) and one nuclear marker (ITS2) to explore genetic diversity between populations of $B$. tenagophila (d'Orbigny), the most common intermediate host for Schistosoma mansoni in southeast Brazil. The snails were collected in freshwater bodies along the southern coastal region of Ribeira do Iguape river basin and along the northern coastal region of the state of São Paulo, Brazil. The estimates of genetic differentiation between the populations $(\Phi)$ indicate that there is no genetic isolation between northern and southern populations. The haplotype diversity observed in B. tenagophila shows a complex pattern of distribution: in the southern region, the genetic variation in B. tenagophila is partitioned into small and more heterogeneous mitochondrial haplotypes, whereas in the northern region there were one to three homogeneous haplotypes. The results may suggest a different colonisation history across the study area.
\end{abstract}

KEY WORDS: Biomphalaria tenagophila, genetic differentiation, 16SrRNA mitochondrial DNA, ITS2, COI, schistosomiasis

\section{INTRODUCTION}

The freshwater snail Biomphalaria tenagophila (d'Orbigny, 1835) is widely distributed in the Neotropics acting as an intermediate host for Schistosoma mansoni in southeast Brazil (PARAENSE 2001). As other Hygrophila, B. tenagophila is able to self- and cross-fertilise. Under experimental conditions, B. tenagophila showed high rates of self-fertilisation (GUIMARÃES et al. 2016) suggesting that this mode of reproduction is an important and efficient component of the mating system in the species.

There is evidence of partition of genetic variation in the genus Biomphalaria in different mitochondrial and nuclear haplotypes on a fine geographical scale, indicating that even geographically close populations are genetically differentiated (MULVEY \& VRIJENHOEK
1982, LANGAND et al. 1999, MAVÁREZ et al. 2002, TUAN \& SANTOS 2007, TUAN et al. 2012). The structuring of the genetic variability of Biomphalaria populations on a fine geographical scale may be a result of reproductive characteristics and physiological adaptations that allow the snails to survive droughts and floods through desiccation by reducing their metabolic activity (BARBOZA et al. 1985, VIANEY-LIAUD \& LANCASTRE 1986, TUAN \& SiMÕES 1989, BARBOSA et al. 2012, WEIR \& SALICE 2012).

In São Paulo state, Brazil, there are two distinct drainage regions. In the northern region, the freshwater ecosystems are formed by independent rivers which start in the Serra do Mar mountain range and flow into the coastal plain (HENRIQUES et al. 2015). In 
the southern region, the Serra do Mar gives way to the Ribeira do Iguape valley which consists of large uninterrupted plains, dominated by the Ribeira do Iguape river, that flow from the foothills of Paranapiacaba mountains in southern Brazil to the Atlantic Ocean (SEVÁ FILHO \& KALINOWSKI 2012). The tributaries of the Ribeira do Iguape flow side-by-side in close proximity (THEODOROVICZ \& THEODOROVICZ 2007). These regions are geographically separated by the Jureia Ecological Reserve, an area with intact habitats (POR \& IMPERATRIZ-FONSECA 1984).

The restricted natural level of connectivity amongst these drainage systems thereby offers an opportunity to speculate on the reasons why the freshwater discontinuity could impact the genetic variability of $B$. tenagophila, a species spread over both the southern and the northern freshwater systems.
In this study, PCR-amplified sequences from COI and 16SrDNA (16S) mitochondrial genes and the second internal transcribed spacer of nuclear ribosomal DNA (ITS2) were used to analyse the genetic variation in B. tenagophila. The mitochondrial genes were used because of their efficacy in inferring genetic patterns in populations associated with the effects of demographic variation within a species (AVISE et al. 1984) and ITS2 because it had previously yielded robust phylogenetic signals in the characterisation of genetically differentiated lineages of $B$. tenagophila (TUAN \& SANTOS 2007).

Our findings show genetic population fragmentation of B. tenagophila in different population units within the southern and northern regions rather than between them.

\section{MATERIAL AND METHODS}

\section{STUDY AREA}

A total of 1,601 specimens were collected in thirty sites in freshwater ditches, streams and canals in the northern and southern regions along the coast of the state of São Paulo. In the northern region, snails were collected in Caraguatatuba, São Sebastião and Ilhabela, a municipality on the island of São Sebastião, which is $2.4 \mathrm{~km}$ from the mainland. In the southern region, snails were collected in Registro, Itariri and
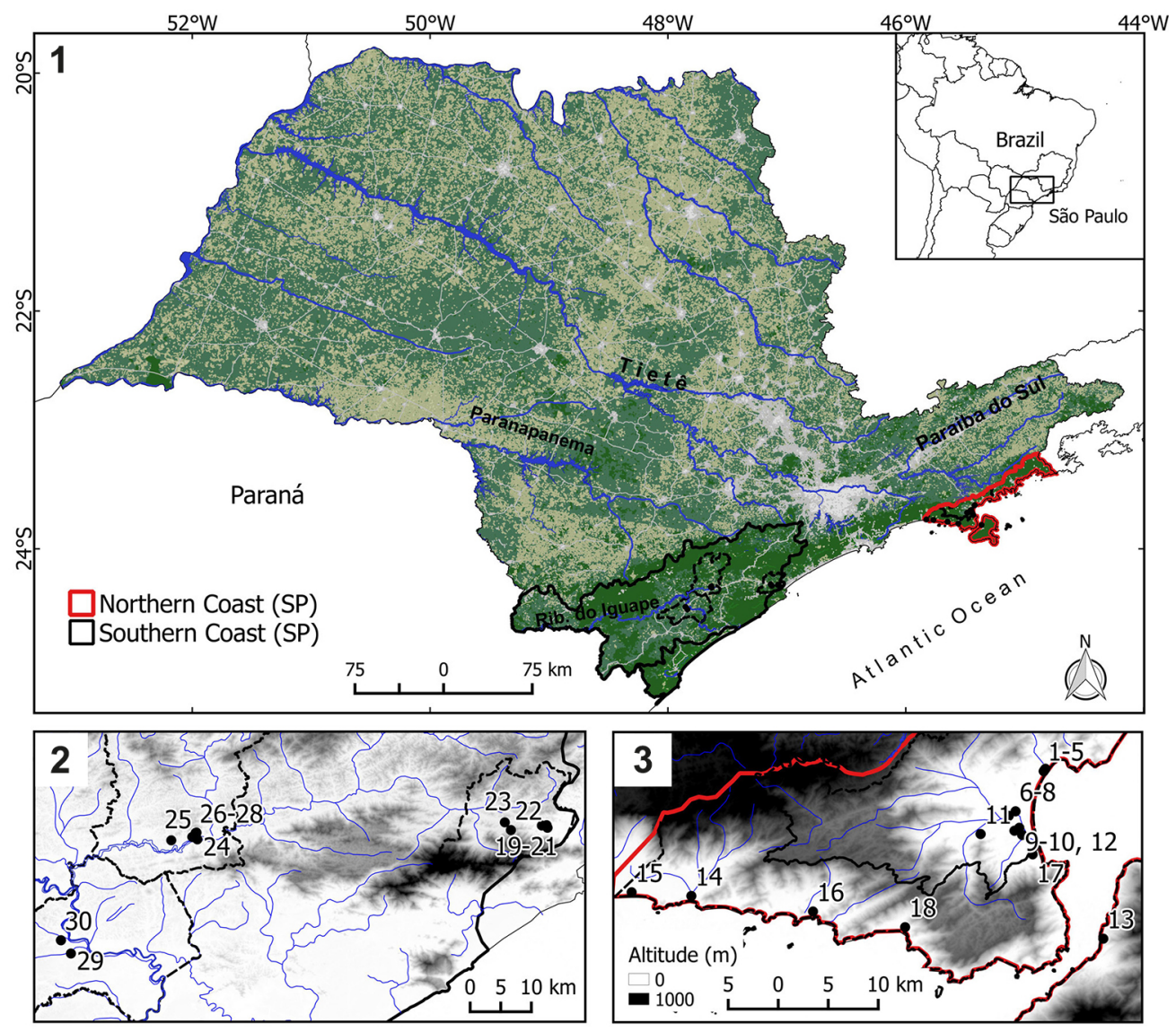

Figs 1-3. Geographical location of the sampling sites: 1 - northern and southern regions; 2 - southern region (Itariri: 19-23; Juquia: 24-28, Registro: 29-30); 3 - northern region (Caraguatatuba: 1-12; Ilhabela: 13; São Sebastião: 14-18) 
Table 1. Coordinates of sampling sites along the southern Atlantic coast in the state of São Paulo, Brazil. Code GenBank of 60 sequences of 16 S, 38 sequences of COI and 31 sequences of ITS2

\begin{tabular}{|c|c|c|c|c|c|c|c|}
\hline \multirow{2}{*}{$\begin{array}{r}\text { Region } \\
\text { Northern }\end{array}$} & \multirow{2}{*}{$\begin{array}{c}\text { sampling site* } \\
1-5\end{array}$} & \multicolumn{2}{|c|}{ Coordinates } & \multirow{2}{*}{$\begin{array}{l}\text { Code } \\
\text { N10 }\end{array}$} & \multirow{2}{*}{$\begin{array}{c}16 S \\
\text { KF840610 }\end{array}$} & \multirow{3}{*}{$\begin{array}{c}\text { COI } \\
\text { KF926106 } \\
\text { KF926105 }\end{array}$} & \multirow{2}{*}{$\begin{array}{c}\text { ITS2 } \\
\text { KF840649 }\end{array}$} \\
\hline & & \multirow[t]{2}{*}{$23^{\circ} 38^{\prime} 03.2^{\prime \prime S}$} & \multirow[t]{2}{*}{$45^{\circ} 25^{\prime} 14.3^{\prime \prime} \mathrm{W}$} & & & & \\
\hline & & & & N11 & KF840615 & & \\
\hline & & \multirow{2}{*}{$23^{\circ} 37^{\prime} 59.6^{\prime \prime} \mathrm{S}$} & \multirow[t]{2}{*}{$45^{\circ} 25^{\prime} 11.4^{\prime \prime} \mathrm{W}$} & N17 & KF840601 & & \\
\hline & & & & N18 & KF840587 & & \\
\hline & & \multirow[t]{2}{*}{$23^{\circ} 37^{\prime} 55.7^{\prime \prime S}$} & \multirow[t]{2}{*}{$45^{\circ} 25^{\prime} 08.8^{\prime \prime} \mathrm{W}$} & N24 & KF840619 & KF926218 & \\
\hline & & & & N29 & KF840612 & KF926221 & KF840655 \\
\hline & & \multirow[t]{2}{*}{$23^{\circ} 38^{\prime} 04.2^{\prime \prime S}$} & $45^{\circ} 25^{\prime} 14.7^{\prime \prime} \mathrm{W}$ & N30 & KF840614 & KF926217 & \\
\hline & & & & N34 & KF840620 & & \\
\hline & $6-8$ & $23^{\circ} 40^{\prime} 26.1^{\prime \prime S}$ & $45^{\circ} 26^{\prime} 54.3^{\prime \prime} \mathrm{W}$ & N13 & KF840605 & MF380482 & KF840652 \\
\hline & & & & N21 & KF840590 & & \\
\hline & & $23^{\circ} 40^{\prime} 42.2^{\prime \prime S}$ & $45^{\circ} 27^{\prime} 18.5^{\prime \prime} \mathrm{W}$ & N22 & KF840591 & & \\
\hline & & & & N27 & KF840594 & KF926214 & \\
\hline & & & & N31 & KF840597 & KF926215 & \\
\hline & $9-10$ & $23^{\circ} 41 ' 24.3^{\prime \prime S}$ & $45^{\circ} 26^{\prime} 41.2^{\prime \prime} \mathrm{W}$ & N12 & KF840586 & & \\
\hline & & & & N14 & KF840613 & & KF840648 \\
\hline & & $23^{\circ} 41^{\prime} 34.8^{\prime \prime S}$ & $45^{\circ} 26^{\prime} 58.1^{\prime \prime} \mathrm{W}$ & N23 & KF840592 & & KF840654 \\
\hline & & & & N26 & KF840595 & KF926216 & \\
\hline & 11 & $23^{\circ} 41^{\prime} 46.4^{\prime \prime S}$ & $45^{\circ} 28^{\prime} 57.9^{\prime \prime} \mathrm{W}$ & N19 & KF840588 & & KF840653 \\
\hline & & & & $\mathrm{N} 20$ & KF840589 & & \\
\hline & & & & N25 & KF840593 & & \\
\hline & & & & N28 & KF840596 & KF926220 & \\
\hline & 12 & $23^{\circ} 41^{\prime} 49.5^{\prime \prime S}$ & $45^{\circ} 26^{\prime} 30.8^{\prime \prime} \mathrm{W}$ & N1 & KF840606 & KF926136 & \\
\hline & & & & $\mathrm{N} 2$ & KF840611 & KF926138 & KF840656 \\
\hline & & & & N8 & KF840608 & & KF840650 \\
\hline & & & & N15 & KF840603 & KF926222 & KF840651 \\
\hline & & & & N33 & KF840598 & & \\
\hline & & & & N35 & & & KF840657 \\
\hline & 13 & $23^{\circ} 47^{\prime} 56.4^{\prime \prime S}$ & $45^{\circ} 21^{\prime} 44.0^{\prime \prime} \mathrm{W}$ & N16 & KF840599 & KF926212 & \\
\hline & & & & N32 & KF840600 & KF926213 & KF840664 \\
\hline & 14 & $23^{\circ} 45^{\prime} 25.3^{\prime \prime S}$ & $45^{\circ} 46^{\prime} 00.7^{\prime \prime} \mathrm{W}$ & N7 & KF840607 & MF380479 & KF840661 \\
\hline & & & & N9 & KF840618 & MF380481 & KF840660 \\
\hline & 15 & $23^{\circ} 45^{\prime} 12.2^{\prime \prime S}$ & 4549'31.9"W & N6 & KF840617 & MF380478 & KF840663 \\
\hline & 16 & $23^{\circ} 46^{\prime} 20.2^{\prime \prime S}$ & $45^{\circ} 38^{\prime} 50.5^{\prime \prime W}$ & N3 & KF840604 & MF380475 & KF840658 \\
\hline & 17 & $23^{\circ} 42^{\prime} 58.4^{\prime \prime S}$ & $45^{\circ} 25^{\prime} 53.7^{\prime \prime W}$ & N5 & KF840602 & MF380477 & KF840662 \\
\hline & 18 & $23^{\circ} 47^{\prime} 15.6^{\prime \prime S}$ & $45^{\circ} 33^{\prime} 24.9^{\prime \prime} \mathrm{W}$ & $\mathrm{N} 4$ & KF840609 & MF380476 & KF840659 \\
\hline Southern & 19 & $24^{\circ} 18^{\prime} 13.6^{\prime \prime S}$ & $47^{\circ} 04^{\prime} 31.7^{\prime \prime} \mathrm{W}$ & S17 & KF840636 & KF926210 & KF840678 \\
\hline & 20 & $24^{\circ} 18^{\prime} 11.8^{\prime \prime S}$ & $47^{\circ} 04^{\prime} 04.1^{\prime \prime} \mathrm{W}$ & S15 & KF840627 & KF926209 & KF840676 \\
\hline & & & & S16 & KF840645 & & \\
\hline & 21 & $24^{\circ} 18^{\prime} 26.3^{\prime \prime S}$ & $47^{\circ} 03^{\prime} 58.9^{\prime \prime} \mathrm{W}$ & $\mathrm{S} 12$ & KF840644 & MF380480 & KF840674 \\
\hline & & & & S19 & KF840646 & KF926207 & \\
\hline & & & & S20 & KF840647 & & \\
\hline & 22 & $24^{\circ} 18^{\prime} 39.9^{\prime \prime S}$ & $47^{\circ} 07^{\prime} 31.4^{\prime \prime} \mathrm{W}$ & S13 & KF840628 & KF926206 & KF840675 \\
\hline & & & & S14 & KF840635 & & KF840677 \\
\hline & 23 & $24^{\circ} 17^{\prime} 55.0^{\prime \prime S}$ & $47^{\circ} 08^{\prime} 06.8^{\prime \prime} \mathrm{W}$ & S18 & KF840638 & KF926211 & KF840679 \\
\hline & 24 & $24^{\circ} 19^{\prime} 33.6^{\prime \prime S}$ & $47^{\circ} 37^{\prime} 53.5^{\prime \prime} \mathrm{W}$ & S5 & KF840630 & KF926147 & KF840673 \\
\hline & & & & S6 & KF840633 & KF926151 & \\
\hline & & & & S7 & KF840634 & KF926149 & KF840672 \\
\hline & 25 & $24^{\circ} 19^{\prime} 39.5^{\prime \prime S}$ & $47^{\circ} 40^{\prime} 25.0^{\prime \prime} \mathrm{W}$ & S24 & MF380486 & KT225580 & \\
\hline & 26 & $24^{\circ} 18^{\prime} 56.7^{\prime \prime S}$ & $47^{\circ} 38^{\prime} 03.1^{\prime \prime} \mathrm{W}$ & S8 & KF840631 & KF926148 & KF840669 \\
\hline & & & & S9 & KF840632 & & KF840671 \\
\hline & & & & $\mathrm{S} 10$ & KF840629 & & \\
\hline & 27 & $24^{\circ} 18^{\prime} 55.1^{\prime \prime S}$ & $47^{\circ} 37^{\prime} 58.6^{\prime \prime} \mathrm{W}$ & $\mathrm{S} 21$ & MF380483 & KT225577 & \\
\hline & & & & S22 & MF380485 & KT225579 & \\
\hline & & & & $\mathrm{S} 23$ & MF380484 & KT225578 & \\
\hline & & & & S25 & MF380487 & & \\
\hline & & & & $\mathrm{S} 26$ & MF380488 & & \\
\hline & 28 & $24^{\circ} 19^{\prime} 19.7^{\prime \prime S}$ & $47^{\circ} 38^{\prime} 22.9^{\prime \prime} \mathrm{W}$ & $\mathrm{S} 11$ & KF840623 & & KF840670 \\
\hline & 29 & $24^{\circ} 30^{\prime} 37.0^{\prime \prime S}$ & $47^{\circ} 50^{\prime} 07.9^{\prime \prime W}$ & S1 & KF840637 & MF380474 & KF840667 \\
\hline & 30 & $24^{\circ} 29^{\prime} 20.1^{\prime \prime S}$ & $47^{\circ} 51^{\prime} 06.1^{\prime \prime W}$ & S2 & KF840626 & & KF840666 \\
\hline & & & & S3 & KF840625 & KF926153 & \\
\hline & & & & S4 & KF840624 & KF926152 & KF840668 \\
\hline
\end{tabular}

*sampling sites: Caraguatatuba (1-12), Ilhabela (13), São Sebastião (14-18), Itariri (19-23), Juquia (24-28), Registro (29-30). 
Juquiá. The collection points were geo-referenced with a Garmin eTrex 10 (Table 1). Both regions are subject to flooding when the river channels on the plains overflow (SoUZA 2005) (Figs 1-3, Table 1).

\section{DNA EXTRACTION, PCR AMPLIFICATIONS, GENETIC, POPULATION STRUCTURE AND PHYLOGENETIC ANALYSIS}

A portion of each live specimen's foot, large enough to extract DNA using a Qiagen Blood and Tissue kit, was excised. Each snail was then identified taxonomically using the anatomical characteristics of the reproductive system following PARAENSE (1975, 1981). The specimens used for taxonomic identification and genetic study were preserved in Fixative Railliet-Henry's fluid. The genomic DNA obtained from each specimen was stored in $-18^{\circ} \mathrm{C}$ freezers in the Molecular and Biochemical Laboratory at SUCEN The different kinds of molecular markers used in this study were obtained from the same specimen.

Part of the COI gene ( $600 \mathrm{bp})$ was amplified with the LCO1490/HCO2198 primers (FOLMER et al. 1994) as described in PALASIO et al. (2017). The $16 S$ mitochondrial gene was amplified by PCR using the 16SAr and 16SBr primers (PALUMBI 1996) as described in TUAN et al. (2012) and ITS2 was amplified with the ITS2F and ETTS1 primers (VIDIGAL et al. 2000) following the amplification protocol described in TUAN \& SANTOS (2007). All polymerase chain reactions (PCR) were carried out in a total volume of $50 \mu \mathrm{l}$ as described in PALASIO et al. (2017). The amplified ITS2 fragments were cloned using pGEM-T (Promega). Five clones were sequenced for each animal. All amplification reactions were carried out in an MJ Research thermal cycler. PCR products were visualised in agarose gel (1.4\%) stained with Gel Red. DNA fragments were purified with a Qiagen purification kit. DNA concentration was estimated using a Low DNA Mass Ladder (Invitrogen). PCR products were purified with a Qiagen purification kit and then sequenced in the Biotechnology Centre at the Butantan Institute in an ABI3100 automated sequencer (Applied Biosystems ${ }^{\circledR}$ ). The sequences were

\section{RESULTS}

\section{COI, 16S AND ITS2 DIVERSITY}

The final alignment dataset for the 38 sequences of COI, 60 sequences of $16 S$ and 31 sequences of ITS2 displayed a length of 545, 309 and 379 nucleotides, respectively. Collapsing of the sequences into haplotypes resulted in nine unique haplotypes for COI, seven haplotypes for $16 S$ and 11 unique sequences for ITS2 (Table 2). aligned in ClustalX (THOMPSON et al. 1997) and then corrected manually with BioEdit 7.0.5.3 (HALL 1999).

The analyses of genetic parameters in the northern and southern regions were considered separately through genetic diversity measures based on the differences calculated in different sequences. First, genetic differences between $16 S$ sequences were analysed under the Kimura 2-parameter nucleotide-substitution model using PAUP (SWOFFORD 2002). A neighbour-joining consensus tree was generated with 1,000 bootstrap replicates. The tree was used to select sequences for which the COI and ITS2 would be analysed. Sequences that met the following criteria were chosen: belonging to differentiated mitochondrial lineages and having come from different collection points.

All the measures were calculated using DnaSP 5.1 (LIBRADO \& ROZAS 2009). The data set with 38 COI, 60 16S and 31 ITS2 aligned sequences were collapsed into unique COI, $16 \mathrm{~S}$ and ITS2 haplotypes using DNAsp v.5 (LIBRADO \& ROZAS 2009). The COI, $16 S$ and ITS2 sequences were submitted to GenBank.

The relationship between the haplotypes was investigated using algorithms implemented in TCS 2.1 (CLEMENT et al. 2000), which clusters sequences by haplotype, calculates the frequency of these haplotypes in each location and estimates the relationships between them. Analysis of molecular variance (AMOVA) was used to estimate the level of variation amongst and within the northern and southern groups. Genetic structure indices were calculated in Arlequin 3.5.1.2 (EXCOFFIER \& LISCHER 2010). The statistical significance of the AMOVA was calculated after 1,023 permutations of the data to simulate the null hypothesis. Appropriate nucleotide substitution models were selected with MrModeltest 2.3 (NYLANDER 2004).

The intraspecific phylogeny of $B$. tenagophila was inferred using a Bayesian Markov-Chain Monte Carlo (MCMC) analysis in MrBayes 3.1 (HUELSENBECK \& RONQUIST 2001, RONQUIST \& HUELSENBECK 2003). Four simultaneous independent searches were run for $1.5 \times 10^{6}$ generations, with trees saved every 100 generations and with the first 1,500 sampled trees of each search being discarded as "burn-in".

As a general pattern, it was observed that in the southern region, few sequences (1-5) collapsed into more numerous and also, especially for mitochondrial genes, less divergent haplotypes. In contrast, a large number of sequences collapsed into few haplotypes in the northern region. One third of the COI and $16 S$ haplotypes were shared between the northern and southern regions and only one haplotype was shared between the regions for ITS2 (Table 3). 
Table 2. Comparison of COI, 16SrRNA and ITS-2 nucleotide diversity calculated in DNAsp5: N - number of sequences, hnumber of haplotypes, $\mathrm{Hd}$ - haplotype diversity, $\Pi$ - nucleotide diversity, k - average number of nucleotide differences, Fu's Fs (FU 1997: equation 1) and Tajima's D statistics (TAJIMA 1989: equation 38)

\begin{tabular}{lllllrrrr}
\hline & Region & $\mathrm{N}$ & $\mathrm{h}$ & $\mathrm{Hd}$ & \multicolumn{1}{c}{$\Pi$} & $\mathrm{k}$ & \multicolumn{1}{c}{ Fu's Fs } & $\mathrm{D}$ \\
\hline \multirow{2}{*}{ COI } & Northern & 21 & 3 & $0.624 \pm 0.068$ & 0.01201 & 6.543 & 2.20736 & 2.90471 \\
& Southern & 17 & 8 & $0.875 \pm 0.053$ & 0.00880 & 4.794 & -0.84404 & -0.57907 \\
& Overall & 38 & 9 & $0.826 \pm 0.096$ & 0.01232 & 6.717 & 1.36642 & 1.60995 \\
$16 S$ & Northern & 34 & 2 & $0.487 \pm 0.044$ & 0.00318 & 0.973 & 1.29872 & 1.95432 \\
& Southern & 26 & 7 & $0.683 \pm 0.086$ & 0.00489 & 1.495 & -0.23305 & -0.90144 \\
& Overall & 60 & 7 & $0.664 \pm 0.039$ & 0.00515 & 1.575 & -0.23305 & -0.21597 \\
\multirow{6}{*}{ TS2 } & Northern & 17 & 4 & $0.419 \pm 0.141$ & 0.00116 & 0.456 & -1.39391 & -1.37718 \\
& Southern & 14 & 8 & $0.868 \pm 0.076$ & 0.00898 & 3.538 & -0.35833 & -0.24799 \\
& Overall & 31 & 11 & $0.665 \pm 0.096$ & 0.00555 & 2.185 & -1.60338 & -1.24805 \\
\hline
\end{tabular}

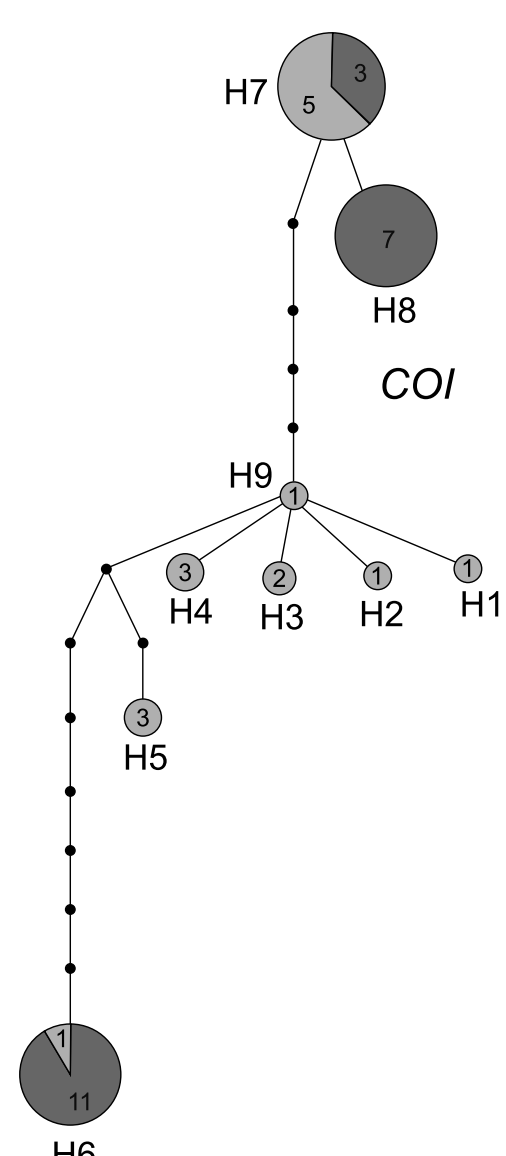

$\mathrm{H} 6$

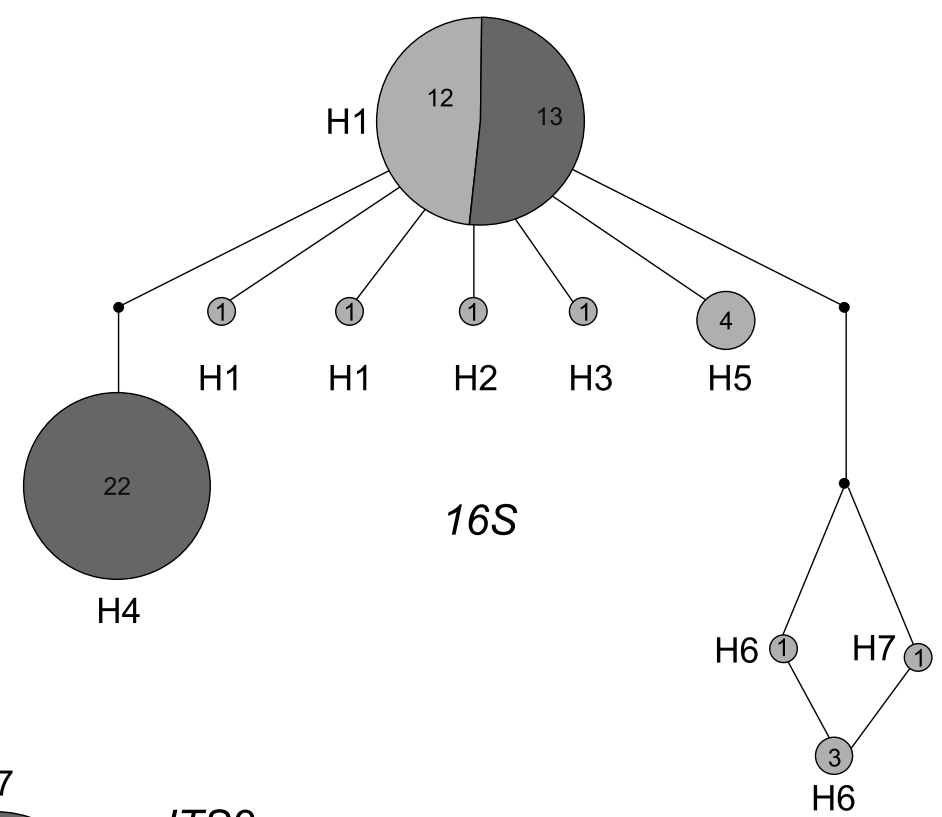

ITS2

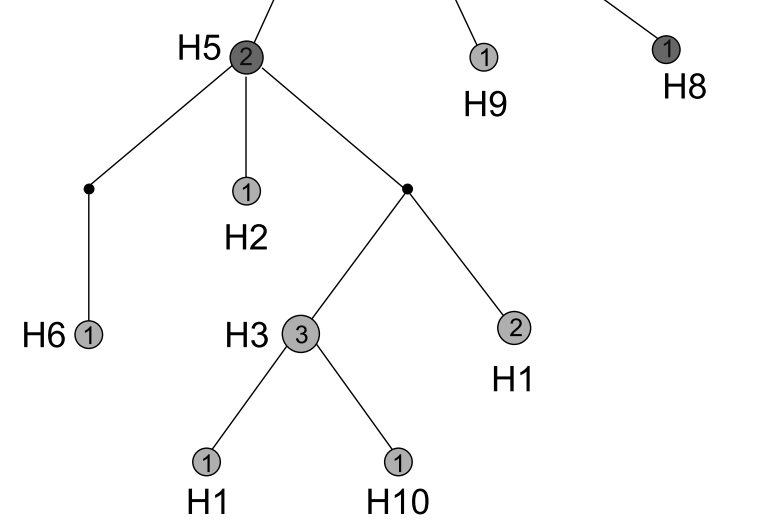

Northern

Southern

Fig. 4. TCS - haplotype networks for Biomphalaria tenagophila based on mitochondrial COI, 16S and nuclear ITS2 sequences. Northern and southern sequences are represented in different shades of grey. Haplotype frequency is shown by the size of each haplotype 
Table 3. Number of COI, 16 S and ITS2 sequences collapsed in haplotypes for Biomphalaria tenagophila sampled in the northern and southern region

\begin{tabular}{cccccccccccc}
\hline \multirow{4}{*}{ COI } & Haplotypes & 1 & 2 & 3 & 4 & 5 & 6 & 7 & 8 & 9 & 10 \\
165 & Northern & 0 & 0 & 0 & 0 & 0 & 11 & 3 & 7 & 0 & - \\
& Southern & 1 & 1 & 2 & 3 & 3 & 1 & 5 & 0 & 1 & - \\
& Northern & 13 & 0 & 0 & 21 & 0 & 0 & 0 & - & - & - \\
& Southern & 14 & 1 & 1 & 1 & 4 & 4 & 1 & - & - & - \\
ITS2 & Northern & 0 & 0 & 0 & 0 & 2 & 0 & 13 & 1 & 1 & 0 \\
& Southern & 2 & 1 & 3 & 1 & 0 & 1 & 5 & 0 & 0 & 1 \\
\hline
\end{tabular}

The diagram with sequences connected according to the number of mutations constructed in a parsimony network using TCS is shown in Fig. 4. As a result, the networks show higher frequencies of minor and unique haplotypes in the southern region than in the northern region.

\section{PHYLOGENETIC ANALYSIS}

The best-fit model of evolution estimated in MrModeltest with AIC parameters for the 38 COI, 60 $16 S$ and 31 ITS2 aligned sequences used to conduct a Bayesian search for the best tree was K80, K2 and JC, respectively (Fig. 5).

\section{ANALYSIS OF THE POPULATION GENETIC STRUCTURE}

The results of AMOVA show that the highest values for genetic diversity (>80\%) occur within regions and a smaller percentage (13-25\%) was found in both the northern and southern regions (Table 4). The estimates of genetic differentiation between the populations $(\Phi)$ indicate that there is no genetic isolation between the northern and southern populations. AMOVA calculated for COI, 165 genes and ITS2 showed that the percentage of genetic variation within regions $(75-80 \%)$ is three to four times as high as it is amongst snails collected in hydrologically disconnected regions (20-24\%).
$\mathrm{COI}$
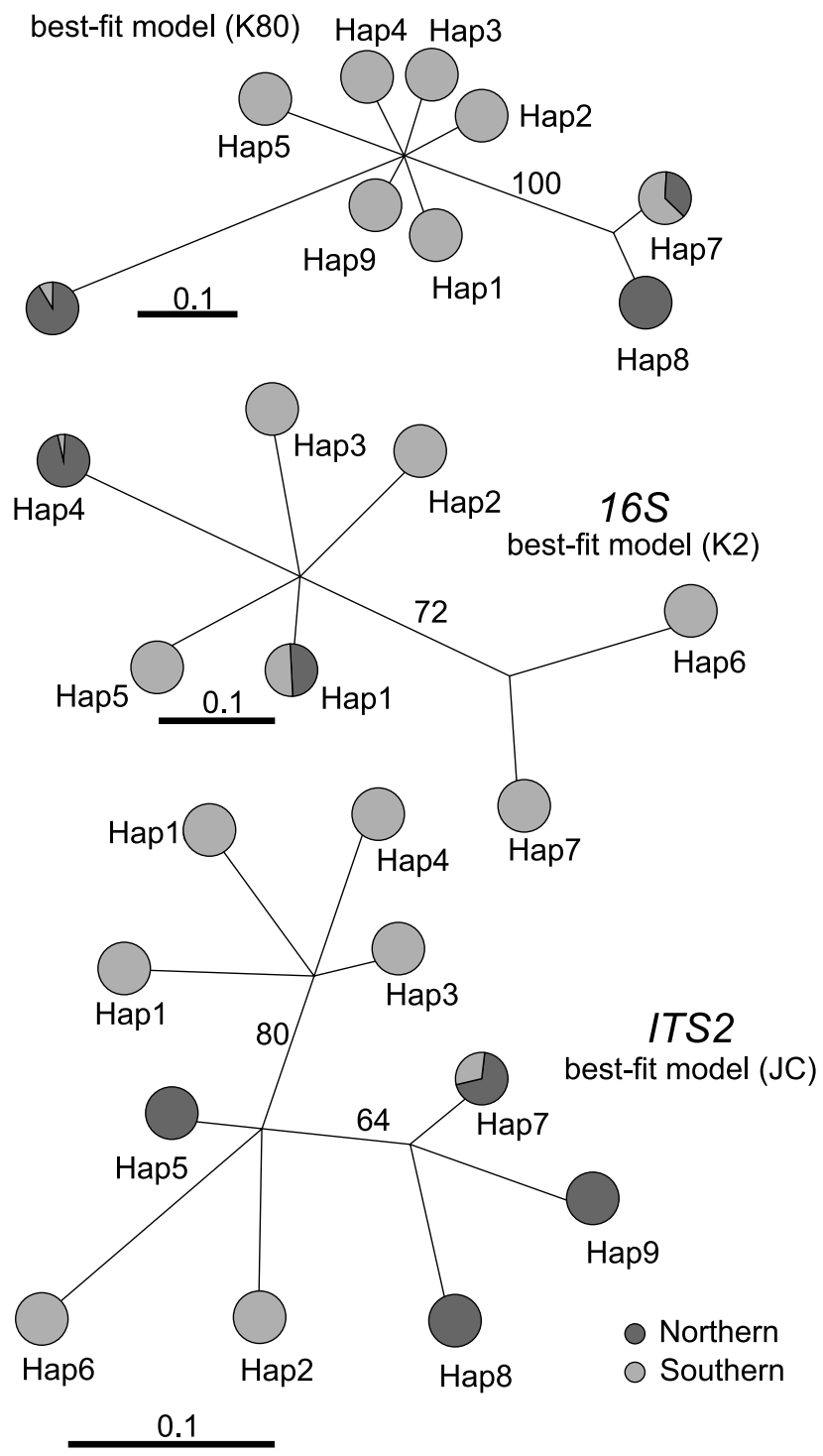

Fig. 5. Unrooted trees inferred under Bayesian approach with COI, 16SrRNA and ITS2 haplotypes of Biomphalaria tenagophila. Bayesian posterior probabilities given above each branch. (Average standard deviations of split frequencies for COI, 16 S and ITS2 were 0.003889, 0.001944 and 0.002682 , respectively). The shades of grey match the shades of grey of haplotypes in Fig. 4

Table 4. Analysis of Molecular Variance (AMOVA) amongst and within COI, 16S and ITS2 sequences in samples from the northern and southern regions: d.f. - degrees of freedom, $\Phi$ - fixation index

\begin{tabular}{|c|c|c|c|c|c|c|c|}
\hline & AMOVA & d.f & $\begin{array}{l}\text { Sum of } \\
\text { squares }\end{array}$ & $\begin{array}{c}\text { Variance } \\
\text { components }\end{array}$ & $\%$ variation & $\Phi$ & p-value \\
\hline \multirow[t]{3}{*}{ COI } & Amongst regions & 1 & 2.051 & $0.08961 \mathrm{Va}$ & 19.59 & 0.19593 & 0.00000 \\
\hline & Within regions & 36 & 13.238 & $0.36772 \mathrm{Vb}$ & 80.41 & & \\
\hline & Total & 37 & 124.263 & 3.81945 & & & \\
\hline \multirow[t]{3}{*}{$16 S$} & Amongst regions & 1 & 3.032 & $0.09321 \mathrm{Va}$ & 24.60 & 0.24602 & 0.00000 \\
\hline & Within regions & 58 & 16.568 & $0.28565 \mathrm{Vb}$ & 75.40 & & \\
\hline & Total & 59 & 19.600 & 0.37886 & & & \\
\hline \multirow[t]{3}{*}{ ITS2 } & Amongst regions & 1 & 1.050 & $0.04852 \mathrm{Va}$ & 13.71 & 0.13714 & 0.01466 \\
\hline & Within regions & 29 & 8.853 & $0.30527 \mathrm{Vb}$ & 86.29 & & \\
\hline & Total & 30 & 9.903 & 0.35379 & & & \\
\hline
\end{tabular}




\section{DISCUSSION AND CONCLUSIONS}

The pattern of molecular variation for B. tenagophila is widely different in snails collected within the southern and northern coastal freshwater systems, for both mitochondrial and nuclear markers. It can be concluded that the probability of collecting two genetically different snails seems not to be directly related to the geographical distance between the populations; instead, there is a greater chance of collecting two genetically different snails in the same hydrological ecosystem than in disconnected and distant freshwater systems.

This is in line with the earlier results obtained with mitochondrial and microsatellite markers in Biomphalaria and Bulinus collected in the Neotropics and Africa, which show that genetic variation in snails is in general partitioned into small populations within localities even across geographiclly connected water bodies (SIRE et al. 2001, MAVÁREZ et al. 2002, CHARBONNEL et al. 2002, THIELE et al. 2013, STANDLEY et al. 2014, ZEIN-EDDINE et al. 2017).

Samples collected in the southern region provided the largest set of mitochondrial haplotypes, the higher polymorphisms values on both mitochondrial and nuclear markers and the higher number of singletons in individuals collected across the study area. In the northern region a large number of sequences collapsed into one to three homogeneous haplotypes spread over the entire area. In the light of these results, two significant questions arise: why are some haplotypes unique to the southern region and do not spread over the entire study area, and why in the northern region a clonal pattern of sequences is observed?

In theory newly invasive populations are thought to have a reduced genetic variation compared to their source populations because of the genetic founder effect associated with the initially small population size during colonisation (HANDLEY et al. 2011). The reduced genetic variation amongst specimens collected in the northern region could be the result of a more recent colonisation process.

B. tenagophila from the southern regions might originate from an independent source population, different from the endemic populations restricted to the southernmost inland freshwater systems. The hypothesis is supported by the fact that the southern region is a part of a hot spot corridor for biodiversity inside the Atlantic forest, holding a highly endemic fauna (CARNAVAL et al. 2014). PLENS (2009) and SouZA et al. (2005) found in shell mounds archaeological sites a significant diversity of shells of freshwater bivalves and gastropods which demonstrate, in theory, the ancient high diversity of the malacofauna in the Ribeira do Iguape region. In general terms, our study supports the hypothesis of VAZ (1989). According to this author, the Ribeira do Iguape basin was in the Paleocene the main dispersal route of $B$. tenagophila from inland to the southern coastal region.

The Bayesian analysis yielded trees with almost identical topologies in COI, 16 S and ITS2 with phylogenetic relationships of some haplotypes well solved and some with weak support, especially haplotypes with sequences from the southern region. In general, the Bayesian analysis of the ITS2 sequences corroborates the finding of differentiated $B$. tenagophila sequences as previously observed in the middle Paranapanema (TUAN \& SANTOS 2007).

Understanding the population's genetic structure and the mechanisms of spread of $B$. tenagophila might fill some gaps in the knowledge of schistosome transmission. When the genetic and parasitological data were compared, PALASIO (2013) observed that cercarial shedding of $B$. tenagophila from the northern region was significantly higher $(60-80 \%)$ than in $B$. tenagophila from the southern region. Hence, it could conceivably be hypothesised that schistosomiasis transmission could be largely affected by the natural history of the snails.

\section{ACKNOWLEDGEMENTS}

The authors would like to thank Dr LUIZ Augusto MAGalHâES, Unicamp, for his constructive comments, Dr MARISA CRISTINA DE ALMEIDA GUIMARÃES, SUCEN, for helping with the collection of snails in Itariri, RICARDO SOARES LOPES DE SOUZA for helping in editing the figures and MARINA TUAN MACHADO for review. The work was partly supported by the Superintendência de Controle de Endemias, FAPESP (ref. no. 07/03458-7) and partly by Coordenação de Aperfeiçoamento de Pessoal de Nível Superior (Capes) which provided RAQUEL G. S. PALASIO with a master's fellowship.

\section{REFERENCES}

Avise J. C., Neigel J. E., ARnOld J. 1984. Demographic influences on mitochondrial DNA lineage survivorship in animal populations. Journal of Molecular Evolution 20: 99-105. https://doi.org/10.1007/BF02257369
Barbosa F. S., Pereira C. D. P., ARrudA F. 1985. Competitive interactions between species of freshwater snails. I. Laboratory studies: IC. Comparative survival of Biomphalaria glabrata and B. straminea kept out of wa- 
ter. Memórias do Instituto Oswaldo Cruz 80: 155-157. https://doi.org/10.1590/S0074-02761985000200006

BARboZA D. M., Zhang C., SANTOS N. C., Silva M. M. B. L., Rollemberg C. V. V., Amorim F. J. R., UetA M. T., Melo C. M. DE, AlmeidA J. A. P. DE, Lourdes Sierpe JERALDO V. DE, JESUS A. R. 2012. Biomphalaria species distribution and its effect on human Schistosoma mansoni infection in an irrigated area used for rice cultivation in northeast Brazil. Geospatial Health 6: S103-S109. https://doi.org/10.4081/gh.2012.128

CARNAVALA. C., WALTARIE., RODRIGUES M. T., ROSAUER D., VAN DER WAL J., DAMASCENO R., PRATES I., STRANGAS M., SPANOS Z., Rivera D., PIE M. R., FIRKOWSKI C. R., BORNSCHEIN M. R., RIBEIRO L. F., MORITZ C. 2014. Prediction of phylogeographic endemism in an environmentally complex biome. Proceedings of the Royal Society B, Biological Sciences 281: 1-8. https://doi. org/10.1098/rspb.2014.1461

ChARbONnEl N., ANGERS B., RASATAVOnjIZAY R., BREMOND P., JARNE P. 2002. Evolutionary aspects of the metapopulation dynamics of Biomphalaria pfeifferi, the intermediate host of Schistosoma mansoni. Journal of Evolutionary Biology 15: 248-261. https://doi. org/10.1046/j.1420-9101.2002.00381.x

Clement M., Posada D., Crandall K. A. 2000. TCS: a computer program to estimate gene genealogies. Molecular Ecology 9: 1657-1659. https://doi. org/10.1046/j.1365-294x.2000.01020.x

EXCOFFIER L., LISCHER H. E. 2010. Arlequin suite ver 3.5: a new series of programs to perform population genetics analyses under Linux and Windows. Molecular Ecology Resources 10: 564-567. https://doi.org/10.1111/ j.1755-0998.2010.02847.x

FOlMER O., BLACK M., HOEH W., LUTZ R., VRIJENHOEK R. 1994. DNA primers for amplification of mitochondrial cytochrome $\mathrm{c}$ oxidase subunit I from diverse metazoan invertebrates. Molecular Marine Biology and Biotechnology 3: 294.

FU Y. X. 1997. Statistical tests of neutrality of mutations against population growth, hitchhiking and background selection. Genetics 147: 915-925.

Guimarães M. C. D. A., Menezes R. M. T. D., Tuan R. 2016. Experimental study on reproduction of the freshwater snail Biomphalaria tenagophila (d'Orbigny, 1835). Invertebrate Reproduction \& Development 60: 1-7. https://doi.org/10.1080/07924259.2016.1174156

HALl T. A. 1999. BioEdit: a user-friendly biological sequence alignment editor and analysis program for Windows 95/98/NT. Nucleic Acids Symposium Series 41: 95-98. http://brownlab.mbio.ncsu.edu/JWB/papers/1999Hall1.pdf

Handley L. J. L., Estoup A., Evans D. M., Thomas C. E., Lombaert E., Facon B., AeBi A., Roy H. E. 2011. Ecological genetics of invasive alien species. BioControl 56: 409. https://doi.org/10.1007/s10526-011-9386-2

HenRiques J. M., Silva G. J. C., ASHIKAGA F. Y., HANNER R., FORESTI F., OLIVEIRA C. 2015. Use of DNA barcode in the identification of fish species from Ribeira de Iguape Basin and coastal rivers from São Paulo State (Brazil). DNA Barcodes 3: 118-128. https://doi.org/10.1515/ dna-2015-0015
HUELSENBECK J. P., RONQUIST F. 2001. MRBAYES: Bayesian inference of phylogenetic trees. Bioinformatics 17: 754 755. https://doi.org/10.1093/bioinformatics/17.8.754

LANGAND J., THERON A., POINTIER J. P., DELAY B., JOURDANE J. 1999. Population structure of Biomphalaria glabrata, intermediate snail host of Schistosoma mansoni in Guadeloupe island, using RAPD markers. Journal of Molluscan Studies 65: 425-433. https://doi. org/10.1093/mollus/65.4.425

LiBRADO P., RozAS J. 2009. DnaSP v5: A software for comprehensive analysis of DNA polymorphism data. Bioinformatics 25: 1451-1452. https://doi. org/10.1093/bioinformatics/btp187

Mavárez J., Steiner C., Pointier J. P., Jarne P. 2002. Evolutionary history and phylogeography of the schistosome-vector freshwater snail Biomphalaria glabrata based on nuclear and mitochondrial DNA sequences. Heredity 89: 266-272. https://doi.org/10.1038/ sj.hdy. 6800128

MulVeY M., VRIJeNHOEK R. C. 1982. Population structure in Biomphalaria glabrata: examination of an hypothesis for the patchy distribution of susceptibility to schistosomes. The American Journal of Tropical Medicine and Hygiene 31: 1195. https://doi.org/10.4269/ajtmh.1982.31.1195

NYLANDER J. A. A. 2004. Bayesian phylogenetics and the evolution of gall wasps. Comprehensive Summaries of Uppsala Dissertations from the Faculty of Science and Technology 937.

PALASIO R. G. S. 2013. Polimorfismo dos genes mitocondrial 16S rRNA e nuclear ITS2 em populações de Biomphalaria tenagophila da Bacia Litorânea do estado de São Paulo e estudo da suscetibilidade dos caramujos ao Schistosoma mansoni. Ph.D. Thesis, Universidade Estadual de Campinas, Campinas, São Paulo.

Palasio R. G. S., Guimarães M. C. A., Ohlweiler F. P., TUAN R. 2017. Molecular and morphological identification of Biomphalaria species from the state of São Paulo, Brazil. ZooKeys 668: 11-32. https://doi.org/10.3897/ zookeys.668.10562

PALUMBI S. R. 1996. Nucleic acids II: the polymerase chain reaction. In: Hillis D. M., MORITZ C., MABLE B. K. (eds). Molecular systematics. Sinauer Associates, Inc., Sunderland 2(1): 205-247.

PARAENSE W. L. 1975. Estado atual da sistemática dos planorbídeos brasileiros. Arquivos do Museu Nacional 55: 105-128.

PARAENSE W. L. 1981. Biomphalaria occidentalis sp. n. from South America (Mollusca Basommatophora Pulmonata). Memórias do Instituto Oswaldo Cruz 76: 199-211. https://doi.org/10.1590/S0074-02761981000200011

PARAENSE W. L. 2001. The schistosome vectors in the Americas. Memórias do Instituto Oswaldo Cruz 96: 7-16. https://doi.org/10.1590/ S0074-02762001000900002

PLENS C. R. 2009. O papel dos amontoados de conchas no sambaqui fluvial. Revista de Arqueologia 22: 77-93. https://doi.org/10.24885/sab.v22i2.275

POR F. D., IMPERATRIZ-FONSECA V. L. 1984. The Juréia Ecological Reserve, São Paulo, Brazil - facts and plans. 
Environmental Conservation 11: 67-70. https://doi. org/10.1017/S0376892900013515

RONQUIST F., HUELSENBECK J. P. 2003. MRBAYES 3: Bayesian phylogenetic inference under mixed models. Bioinformatics 19: 1572-1574. https://doi. org/10.1093/bioinformatics/btg180

SeVÁ FilHo A., KalinOwSKI L. M. 2012. River diversion and hydropower plants: The unknown Ribeira Valley (PR-SP). Estudos Avançados 26: 269-286. https://doi. org/10.1590/S0103-40142012000100019

Sire C., LANGAND J., BARRAL V., THÉRON A. 2001. Parasite (Schistosoma mansoni) and host (Biomphalaria glabrata) genetic diversity: population structure in a fragmented landscape. Parasitology 122: 545-554. https://doi. org/10.1017/S0031182001007727

SoUZA C. R. G. 2005. Suscetibilidade morfométrica de bacias de drenagem ao desenvolvimento de inundações em áreas costeiras. Revista Brasileira de Geomorfologia 6: 45-61. https://doi.org/10.20502/rbg.v6i1.38

StANDley C. J., GoOdACRE S. L., WADE C. M., STOTHARD J. R. 2014. The population genetic structure of Biomphalaria choanomphala in Lake Victoria, East Africa: implications for schistosomiasis transmission. Parasites \& Vectors 7: 524. https://doi.org/10.1186/ s13071-014-0524-4

SWOFFORD D. L. 2002. PAUP*. Phylogenetic Analysis Using Parsimony (*and Other Methods). Version 4. Sinauer Associates, Sunderland, Massachusetts.

TAJIMA F. 1989. Statistical method for testing the neutral mutation hypothesis by DNA polymorphism. Genetics 123: 585-595.

Theodorovicz A., Theodorovicz Â. M. D. G. 2007. Atlas geoambiental: subsídio ao planejamento territorial e à gestão ambiental da bacia hidrográfica do rio Ribeira de Iguape. 2. ed. Rev. CPRM, São Paulo.

Thiele E. A., CORRÊA OliveirA G., GAZzinelli A., MinCHELlA D. J. 2013. Elucidating the temporal and spatial dynamics of Biomphalaria glabrata genetic diversity in three Brazilian villages. Tropical Medicine \& International Health 18: 1164-1173. https://doi. org/10.1111/tmi.12164

Thompson J. D., GiBson T. J., PleWNiak F., JEANMOUGin F., HigGINS D. G. 1997. The CLUSTAL_X windows interface: flexible strategies for multiple sequence alignment aided by quality analysis tools. Nucleic Acids Research 25: 4876-4882. https://doi.org/10.1093/ nar/25.24.4876
Tuan R., OHWeiller F., Palasio R. G. S., Zanna R., GuimARÃES M. C. A. 2012. Pattern of genetic divergence of mitochondrial DNA sequences in Biomphalaria tenagophila complex species under barcoding perspective. In: ROKNI M. B. (ed.). Schistosomiasis. IntechOpen, London, pp. 293-310. https://doi.org/10.5772/25550

TUAN R., SANTOS P. 2007. ITS2 variability of Biomphalaria (Mollusca, Planorbidae) species from the Paranapanema Valley (São Paulo State, Brazil): diversity patterns, population structure and phylogenetic relationships. Genetics and Molecular Biology 30: 139-144. https:// doi.org/10.1590/S1415-47572007000100024

TUAN R., SimÕES L. C. G. 1989. Spermatogenesis and desiccation in Biomphalaria tenagophila (Orbigny, 1835) (Gastropoda, Planorbidae). Revista Brasileira de Genetica Ribeirão Preto 12: 881-885.

VAZ J. F. 1989. Distribuição e dispersão de Biomphalaria tenagophila (d'Orbigny, 1835) (Gastropoda-Pulmonata). Ciência e Cultura 41: 14-27.

VIANEY-LIAUD M., LANCASTRE F. 1986. Laboratory studies on the desiccation of immature stages of the freshwater snail Biomphalaria glabrata. Annals of Tropical Medicine and Parasitology 80: 257-259. https://doi.org/10.1080 /00034983.1986.11812011

Vidigal T. H. D. A., Kissinger J. C., CAldeira R. L., PireS E. C. R., Monteiro E., Simpson A. J. G., CARvalho O. S. 2000. Phylogenetic relationships among Brazilian Biomphalaria species (Mollusca: Planorbidae) based upon analysis of ribosomal ITS2 sequences. Parasitology 121: 611-620. https://doi.org/10.1017/ S0031182000006831

WeIR S. M., SALICE C. J. 2012. High tolerance to abiotic stressors and invasion success of the slow growing freshwater snail, Melanoides tuberculatus. Biological Invasions 14: 385-394. https://doi.org/10.1007/ s10530-011-0084-X

ZEIN-EDdine R., DJUIKWO-TEUKENG F. F., DAR Y., DREYFUSS G., VAN DEN BROECK F. 2017. Population genetics of the Schistosoma snail host Bulinus truncatus in Egypt. Acta Tropica 172: 36-43. https://doi. org/10.1016/j.actatropica.2017.04.002

Received: June 26th, 2018

Revised: October 25th, 2018

Accepted: October 27th, 2018

Published on-line: December 4th, 2018 